\title{
Development of Learning Media Assisted by Interactive PowerPoint in Thematic Learning at Elementary Schools
}

\author{
Eva Betty Simanjuntak ${ }^{1 *}$, Naeklan Simbolon ${ }^{2}$, Meri Yanti Pasaribu ${ }^{3}$, Sorta Simanjuntak ${ }^{4}$ \\ ${ }^{1-4)}$ Faculty of Education, Medan State University, Indonesia \\ *evabettysimanjuntak@yahoo.co.id
}

\begin{abstract}
This study aimed to examine the effectiveness of group counseling through the self-instruction technique empirically based on observational learning (SIBOL) to foster a steady and great attitude in life as a student. This study used quantitative methods by "within-group or individual design" through equivalent time-series design, pre-test, posttest 1 and post-test 2 continuously with self-efficacy scale (being steady in a life), and conducted by 6 students who had low self-efficacy in the academic context. Data analysis used t-test calculations and showed results that group counseling through SIBOL techniques being more effective to improve student's self-efficacy, as evidenced by an increasing score from pre-test to post-test 2 namely $16 \%$.
\end{abstract}

Keywords: Group Counseling through SIBOL technique, Academic Contexts, University

\section{Introduction}

The student degree that was embedded not only like a formality attribute that given to individuals when they become one of the 'residents' of a university or campus (graduation), but also created individuals who were responsible for language, morality, thought and selfregulation whether written and orally. Students who were able to be responsible for language, morality, thinking and self-regulation, not just imitating the mechanism by observing the surrounding environment, but also they would doing cognitive process automatically and consider each experience, morals, perspectives or critical thinking ways. Bandura revealed that observational learning is a cognitive process that involves language, morality, and perception of a person's behavior [1]. It meant that when they have to respond, students as an individual still considered the positive and negative impacts to give respond through their style and languages.

These considerations that was being the task of development, sometimes made students feel that what they have done was appropriate or not ethically when they faced people who more higher than their level (such as Lecturer, Chancellor, Dean, Head of Study Program, Study Program Secretary, Activity Coordinator, Administration or staff and so on) and people who was in same level with them (such as their classmates or another friends from study programs, partner organizations, etc.). Their concerns in socializing with the campus community to the academic context in the classroom, among the organization and university, was required them to become a 'smart' personality to create the expected student characteristics without becoming an in lander who only bowed to the campus authorities.

The constancy of student self was caused by having a great life stance. Yusuf [2] stated that the age range of students is 18 to 25 years (late adolescence), so that task of development 
for students in this age is stability in the establishment of life. However, after doing a selfefficacy scale (stability in the establishment of life) that became a pilot test, there were still some students who did not have stability in their establishment of life, including these results of (1) High 9,2\%, (2) Medium 36,3\%, (3) Low 54,5\%. If it viewed from the results of pilot tests that have been conducted, it was necessary to conduct services that related to learning skills by observing, maintaining and imitating behavior explicitly from students or other agents. It was in line with the research of Borsa et al., and Morse [2] who states that "most students learn by observing the behavior of other individuals with emerging learning mechanisms such as role modeling, imitation or observational learning."

Observing learning was the ability of individuals to change behavior based on native information obtained from other individuals or agents in their environment indirectly and modeled explicitly, especially if the agent was not far of their age. It was in line with the research [3] who states that peer modeling is an effective way of giving confidence to students in making wise decisions through seeing directly the same age model (peer). Ambarsari also proved that "peer group counseling students are able to improve their confidence by optimizing their potential without taking an attitude that can harm themselves or intended person." Observational learning was not only an activity that imitated the behavior of other agents but also could learn about the dynamics of social life and tried to infer the strengthening functions of other agents by rebuilding the cognition systems so that they would able to achieve their successes with these agents in their lives together (Bandura \& Walter) [4].

Observational learning that used the cognition system would provide a filter for students to change their inappropriate behaviors (maladaptive) into positive behavior through presented live modeling. This confirms that there was still needs a technique that strengthened observational learning, in order to be able to improve the stability of life (principles) for students. Manning, 1991; Fernandez, 1999, Fryling 2011 [5]] said that four theoretical foundations in directing themselves firmly include: attribution theory, theory process in presenting information, self-efficacy theory, and self-regulation theory. Based on these, it became the researchers' basic considerations to integrate the perspective observational learning through self-instruction that implemented for all students in each group format.

The group format that integrated with observational learning based on self-instruction techniques, summarized in several activities, including: (1) The researcher played a video for example self-instruction technique to students in the first step namely overt (voiced loudly and strongly), (2) students imitated self-instruction in the second step namely overt external guidance (still voiced loudly and strongly), then the third step namely overt self-guidance (by verbalization within a loud voice and strongly), (3) the researcher did monitors and directed students to do self-instruction with the fourth step, namely faded overt self-guidance (applying performance properly like whispering self-instruction repeatedly and praising self alone, (4) students familiarized their self to covert self-instruction without external guidance's.

These steps would be monitored sequentially using a success indicator sheet based on observational learning. (a) The first step of the self-instruction was integrated with the attentional process, (b) The second, third and fourth steps would be integrated directly with the retention process based on a review of success or failure when doing the complete selfinstruction process, (c) The motor reproduction processes was application steps with behavior, by changing the cognitive picture into behavior through evaluating based on the goals of a learner, (d) The final step and needed for self-awareness of the learner was the motivational process. Through high motivation would stimulate students to do a behavior that was similar to what they wanted to do (object: video self-instruction and ideal attitudes that exemplified 
by students) [1,6]. For more details, it could be seen in Figure 2 . On the basis above, the purpose of this study was to examine the effect of SIBOL technique group counseling to improve student self-efficacy in an academic context. The hypothesis that would be answered about the significant influence of SIBOL technique of group counseling on student's selfefficacy.

\section{Research Method}

This research was a quantitative study through a within group or individual design study, because this research design's was used to test the effect of treatment on individual research subjects [7]. The experimental research designs through within group or individual design that used equivalent time series designs[5,7]. This design consisted of pretest 1 and posttests 2 , with forms $\mathrm{A}, \mathrm{B}$, and $\mathrm{C}$.

According to the ADDIE research development model [5] explains that conceptually there are several design steps of this research model, namely as follows:

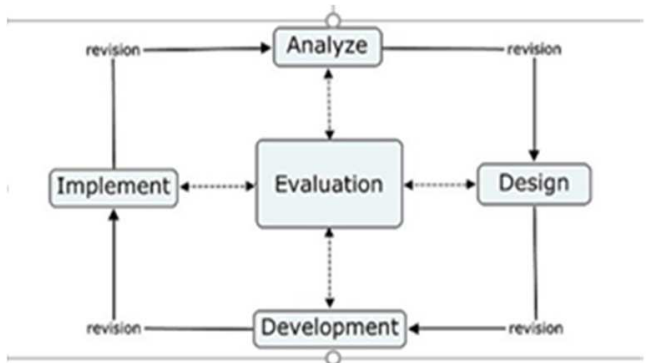

Figure 1. Schema of Development of ADDIE Model

This development research procedure adopts the ADDIE model, which is a development model consisting of 5 stages including, analysis, design, development, implementation and evaluation. Researchers modify the development model as needed.
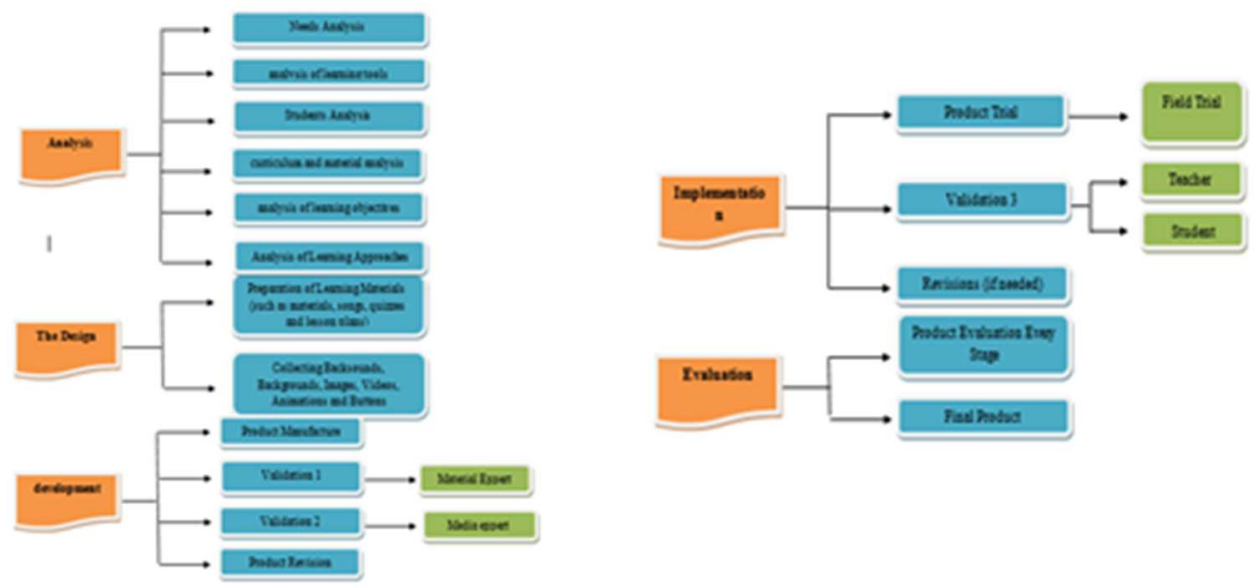

Figure 2. Procedure of Interactive Power point Media Development 
This study uses several instruments which are divided based on data acquisition sources consisting of expert validation instruments and instrument validation of teachers and students during field trials. The research instrument has been validated by FIP PGSD lecturer at Universitas Negeri Medan. The qualitative data in this study was in the form of criticism and suggestions raised by material experts, media experts and fourth grade elementary school teachers. The data is then analyzed as a basis to improve and determine the feasibility of the resulting development product.

Quantitative data is the result of assessment using a scaling scale. This quantitative data can be obtained from the results of the validation of media experts, material experts, teachers as education practitioners and students. The scale of the assessment of this interactive power point-assisted learning media uses a Likert scale with five choices (scale of five). The results of the validation data of material experts, media experts and education practitioners are done by giving a score that is score 1 for assessment is not good, score 2 is not good, score 3 is good enough, score 4 is good, and score 5 is very good. For the questionnaire statement the response of students in field trials containing positive and negative items. In the statement of positive items is done by giving a score that is 1 for the assessment does not agree, a score of 2 disagrees, a score of 3 is neutral, a score of 4 agrees and a score of 5 strongly agrees while for the statement of a negative item is done by giving a score of 1 for the assessment strongly agrees, the score 2 agrees, a score of 3 is neutral, a score of 4 is less agreeable and a score of 5 for the assessment does not agree.

\section{Results and Discussion}

Questionnaire related to students' responses regarding interactive power point learning media consists of aspects of interest, aspects of appearance, aspects of language and aspects of the use of interactive power point media for students. The results of the assessment in the field trials obtained an average of 4.81 and included in the category of "Very Good". Assessment was obtained based on the assessment of material experts, media experts, education practitioners and fourth grade students of SDN 066434 Kota Bangun. Media assessment is based on material experts, both natural science experts and Indonesian language material experts, including material content aspects, material presentation aspects and language aspects. Aspects assessed from media experts include aspects of content or content, aspects of design or appearance and aspects of use and presentation, as well as aspects of language.

Table 2. Recapitulation of Media Validation for Each Stages

\begin{tabular}{|c|c|c|c|}
\hline \multirow[t]{2}{*}{ No. } & \multirow[t]{2}{*}{ Validator } & \multicolumn{2}{|c|}{$\begin{array}{l}\text { Interactive results of Media } \\
\text { Power point validation }\end{array}$} \\
\hline & & Skor & Category \\
\hline 1. & Expert in Natural Sciences & 4,6 & Very Good \\
\hline 2. & Expert in Bahasa & 4,5 & Very Good \\
\hline 3. & Expert in media & 4,6 & Very Good \\
\hline 4. & Educational Practitioners & 4,7 & Very Good \\
\hline \multicolumn{2}{|c|}{ 5. Field Trial } & 4,8 & Very Good \\
\hline \multicolumn{2}{|r|}{ Amount } & \multicolumn{2}{|c|}{23,2} \\
\hline \multicolumn{2}{|c|}{ Average } & \multicolumn{2}{|c|}{4,64} \\
\hline & Category & \multicolumn{2}{|c|}{ Very Good } \\
\hline
\end{tabular}


Educational practitioners also provide an assessment of aspects of interactive power point media, aspects of material presentation, aspects of learning and aspects of language. Trials on students assess aspects of interests, aspects of appearance, aspects of language and aspects of usefulness. The recapitulation of the media validation from each stage can be seen in the following Table 2 above. The overall validation score is 23.2. From these data obtained an average of 4.6 and included in the category of "Very Good".

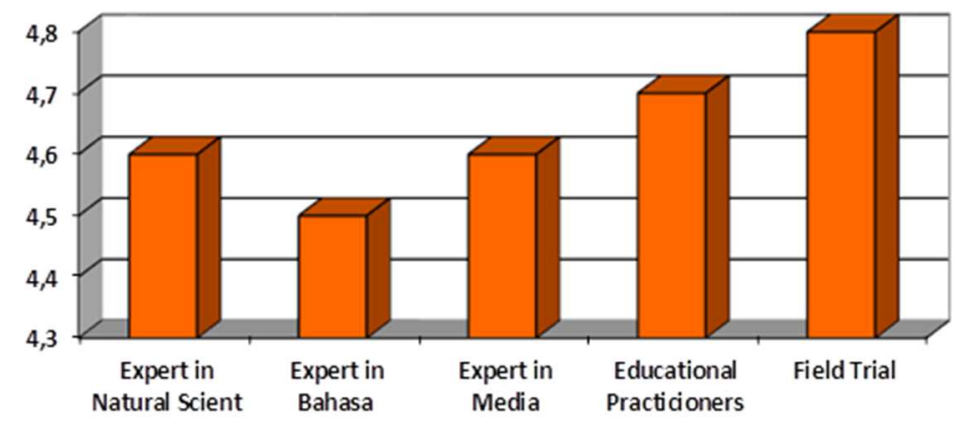

Figure 4. Media Validation for Each Stages

Table 3. Recapitulation of Media Feasibility for Each Stages

\begin{tabular}{ccccc}
\hline \multirow{2}{*}{ No. } & \multirow{2}{*}{ Validator } & \multicolumn{3}{c}{ Feasibility Results of Interactive Power-point Media } \\
\cline { 3 - 5 } & Average & Percent & Category \\
\hline 1. & Expert in Natural Sciences & 46 & $92 \%$ & Very Decent \\
2. & Expert in Bahasa & 45 & $90 \%$ & Very Decent \\
3. & Expert in Media & 137 & $92 \%$ & Very Decent \\
4. & Educational Practitioners & 56 & $93 \%$ & Very Decent \\
5. & Field Trial & 2401 & $96 \%$ & Very Decent \\
\hline \multicolumn{2}{c}{ Average } & & $93 \%$ \\
\hline \multicolumn{6}{c}{ Category }
\end{tabular}

Based on table 3 shows that the average percentage of overall feasibility results is $93 \%$ and included in the category "Very Eligible". An assessment of the results of all media eligibility in this \% can be seen in the following diagram

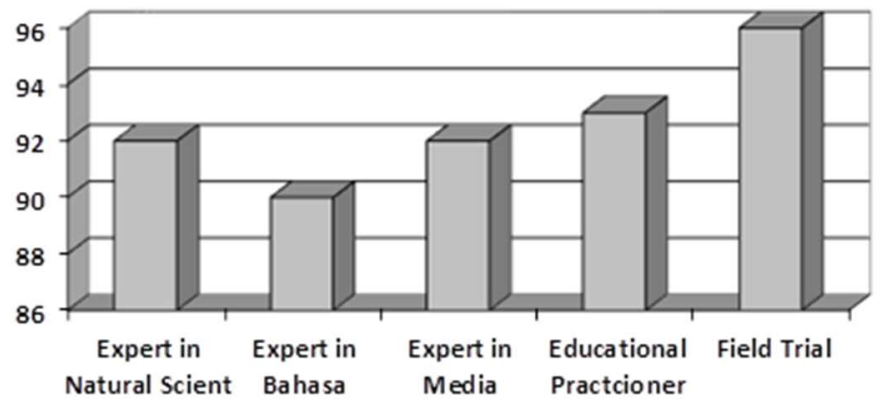

Figure 5. Media Feasibility for Each Stages 
Diagrams 4 and 5 show that learning media assisted by interactive power-points on the theme of my ideals in class IV SDN 066434 Kota Bangun have "Very Good" and "Very Decent" qualities used as learning media in the classroom. This is supported based on the results of research from Masoud Hashemi [8] that Power Point as an innovative tool for teaching and learning in modern classrooms is able to be a means of increasing educational learning tools for teaching and delivering material in by providing a road map, strengthening what is delivered to support the teaching process. Jenny Indratoeti, S Poerwanti [4] stated that this program aims to motivate school teachers to be able to use the Microsoft Power point program, improve the ability of primary school teachers to use media-based technology and increase the creativity of teachers in producing interactive media models using the Power point program. The method used is lecture, question and answer, direct practice/simulation with assistance. In this case, the power-point can be developed in learning and able to provide learning that innovates. In an effort to improve the learning process so that it is effective and functional, then interactive learning media is very important to be utilized. The use of media in the learning process is intended to enhance students' digestibility of the information or learning material provided. With the rapid development of information technology, there are several choices of learning media that are used.

\section{Conclusion}

Based on the results of research and discussion, this research and development can be concluded that: a) The results of validation by natural science material experts obtained an average of 4.6 (Very Good). B) The results of validation by Indonesian material experts obtained an average of 4, 5 (Very Good). C) The results of validation by media experts obtained an average score of 4.6 (Very Good). Assessment by educational practitioners obtained an average score of 4.7 (Very Good), Field trials by students were obtained average score of 4.8 (Very Good), Feasibility Level by IPA material experts in the form of percentage obtained $92 \%$ (Very Eligible), Feasibility by Indonesian material experts is obtained $90 \%$ (Very Eligible), Feasibility by media experts in percentage form obtained $92 \%$ (Very Eligible). The feasibility level of interactive power-point learning media is known based on the assessment of education practitioners, namely grade IV teachers and field trials by grade IV students of SDN 066434 Kota Bangun, Feasibility by education practitioners in the form of a percentage obtained by $93 \%$ (Very Eligible), Eligibility of field trials by students obtained an average of $96 \%$ (Very Eligible)

\section{References}

[1] Jenny Indratoeti S Poerwanti, H. M. (2018). Optimalisasi penggunaan media pembelajaran interaktif dengan Microsoft Power Point Pada Guru-guru Sekolah Dasar. Jurnal Pengabdian dan Pemberdayaan Masyarakat, 2 (2).

[2] Mohammad, Y. (2018). Enhancing Teachers' Literacy Competence Through Critical Writing in The Digital Era. International Journal of Pedagogy and Teacher Education, 2 (2), pp. 401-402.

[3] Murfiah. (2017). Pembelajaran Terpadu Teori dan Praktik Terbaik Di Sekolah Dasar. Bandung: Reflika Aditama.

[4] Bandura, A. \& Walters, R. (1963). Social Learning and Personality Development. New York: Holt, Rinehart \& Winston. 
[5] Sugiyono. (2017). Metode Penelitian Kualitatif, Kuantitatif dan RnD. Bandung: Alvabeta.

[6] Lazic, Z. (2016). Impact of Resilence, ICT Support and Quality of Student's Life on Quality of High Education Process. International Journal for Quality Reseach, 10 (4), pp. 823-838.

[7] Creswell, J. (2015). Educational Research: Planning, Conducting, and Evaluating Quantitative and Qualitative Research. New York: Pearson.

[8] Masoud Hashemi, Masoud Azizinezhad, Masoumeh Farokhi, (2012). Power Point as an innovative tool for teaching and learning in modern classes. Procedia - Social and Behavioral Sciences, 31, pp. $559-563$. 